\title{
PEDAGOGICAL CONDITIONS FOR THE FORMATION OF ECO-VALUES OF FUTURE TEACHERS OF NATURAL SCIENCES: A METHODOLOGICAL APPROACH
}

\section{Rogoza}

The urgency of forming an eco-focused type of understanding nature among modern people has a philosophical and theoretical justification and practical confirmation, related to the sad experience of environmental problems. In turn, this actualizes the task of introducing into the educational process pedagogical conditions, which would stimulate the formation of environmental values of specialists in the specialty 014.15 General Education (Natural Sciences) of the first (bachelor's) level of higher education. These specialists can be potential adherents of the eco-focused type of understanding nature. This task is even more relevant, considering the fact that the axiological component in modern educational programs of the relevant profile is not enough represented little, and the formation of environmental value competencies is not their goal.

The purpose of this study is to clarify the content of the methodological approach regarding verifying the effectiveness of the implementation of certain pedagogical conditions in order to obtain the desired educational result - the formation of environmental values in future teachers of natural sciences.

The research has generalized and systematized scientific methods, which allow determining the effectiveness of pedagogical conditions for the formation of environmental values through the implementation of the author's course "Axiological Pedagogy" and training course "Ensuring the adoption and translation of professional values." The paper presents for the first time a methodological research system that is justified for the analysis of the first systematized and substantiated environmental values as the desired results of the educational process. The article defines peculiarities of application of methods for diagnosing the formation of ecological values in future teachers of natural sciences.

The pilot test of the described methodological research system has proved its validity in pedagogical practice, in particular, to assess the results of the implementation of pedagogical conditions for the formation of environmental values of specialists in specialty 014.15 Secondary education (Natural Sciences) of the first (bachelor's) level of higher education

Keywords: pedagogical theory, pedagogical conditions, axiology, ecological values, means of diagnostics of educational process

Copyright (C) 2020, V. Rogoza. This is an open access article under the CC BY license (http://creativecommons.org/licenses/by/4.0).

\section{Introduction}

The formation urgency of the eco-focused type of nature understanding in a modern human, characterized with acknowledgement of an internal (non-utilitarian value of nature and striving for observance of harmony of "Human - Nature" relation has a logic philosophicaltheoretical substantiation, conditioned by the need of practical solution of ecological problems, faced by mankind. At that eco-focused nature understanding has both individual and social dimensions, confirmed by many modern ecological conceptions, and ecological values are approved not only by human interests, but the vary logic of Nature laws. This approach determined main aims and tasks of introducing pedagogical conditions, stimulating the ecological values formation in experts of specialty 014.15 General education (Natural sciences) of the first (bachelor) level of higher education as potential followers of eco-focused nature understanding, in the educational process.

So, it is necessary to understand that the notion "pedagogical conditions" covers different aspects of all components of the educational process: aims, content, principles, methods, form, means and so on. This notion "may be used for the integral learning-upbringing process at characterizing the pedagogical system or its separate sides or elements" [1]. So, let's accent that in our research the notion "pedagogical conditions" denotes the complex of learning-upbringing arrangements, realized by a higher educational institution in the process of professional training, and directed on the formation of the system of professional competences, students' person development in the professional and universal (humanitarian) senses.

At the same time pedagogical conditions determine the achievement of certain learning results and are themselves a subject of modeling, based on modern educational conceptions and technological approaches to the learning-upbringing process (professional training). So, there is a task not only to determine pedagogical conditions of ecological values formation in future teachers of natural sciences, but also to discover the content of the methodological approach as to checking the effectiveness of their realization for achieving a desired educational result. 


\section{Literary review}

It is necessary to note, that the analysis of special literature and scientific sciences about the chosen topic indicates that the problem of professional competences formation in students of natural specialties was a subject of researches by Ukrainian and foreign scientists. Especially, O. Blashkova devoted her work to the problem of humanistic values formation in students of natural specialties [2], but eco-values as a fundamental value for further professional activity are left beyond her attention. In her turn, N. Gritsay elaborated correspondent pedagogical conditions and means of their diagnostics within the study of the system of methodical training of future biology teachers [3]. These contributions were methodically useful for us, although they didn't directly relate to the question of axiological competence formation. Theoretical and practical results of M. Vasilieva as to deontological training of a teacher are useful in the same aspect [4]. In the process of understanding and determination of the content of the methodological approach to formation and checking of pedagogical conditions of eco-values formation in future teachers of natural sciences we also took into account the research materials of V. Demyanyuk as to value professional orientations formation in professional training [5] and the theses of the scientific work by $\mathrm{O}$. Molchanyuk at determining means for upbringing the value attitude to nature in future biology teachers [6]. At the same time our analysis gives grounds to state that till today just pedagogical conditions of ecovalues formation in future teachers of natural sciences have not been an object of special consideration, just like the content of the methodological approach as to checking the effectiveness of their realization for achieving a desired educational result.

The well-grounded realization of our research conditioned a necessity to address to the problem of formation diagnostics of certain qualities, competences, value characteristics. Our interest was directed on both methods that proved their effectiveness more than once: psychodiagnostic method by S. Schwartz [7], methodology "Value orientations" by M. Rokeach [8], and on the research results in this field by such scientists as: I. Ladanova and V. Urazaeva (diagnostics of motivational orientations) [9], the analytics as to value priorities and their determination in modern corporative institutions, generalized by such researchers as D. Sull, S. Turconi and C. Sull [10].

From another side, the topicality of addressing to this problematic is proved by the fact that we have realized the special analysis of educational programs as to training of experts of specialty 014.15 General education (Natural sciences) of the first (bachelor) higher education level of five educational institutions (Poltava national pedagogical university, named after V.G. Korolenko, Izmail state humanitarian university, Ternolil national pedagogical university, named after V. Gnatyuk, Uman state pedagogical university, named after P. Tichina, Mukachevo state university). It proved that the axiological component in educational programs is little presented, and ecological competences formation is not their goal. So, we undoubtedly may state the fact that actualization of eco-values in the subject position of future teachers of natural sciences in practice is an urgent need that is not enough substantiated at the philosophicaltheoretical level, not completely motivated by realities of ecological problems and at the same time not solved in pedagogical practice.

\section{Aim and tasks of research}

The research aim is to highlight principles of choosing methodical instruments for checking a conceptually separated model of ecological values formation in future teachers of natural sciences.

The following tasks were set for attaining the aim:

1) to highlight the content of the method for diagnosing ecological values formation in future teachers of natural sciences;

2) to characterize peculiarities of its use.

\section{Theoretical presentation of research meth-} odology

For verifying the formulated working hypothesis, namely: a level of ecological values formation in future teachers of natural sciences increases at introducing author pedagogical conditions and the system of specially elaborated arrangements (implementation of the discipline "Axiology" and special training) into the process of their professional training, we used a series of traditional and specially elaborated methods, allowed to diagnose the level of ecological values formation in future teachers of natural sciences at the beginning and at the final stage of the experiment.

An independent variable determined the ecological readiness of future teachers of natural sciences to work by the specialty in the contextual dimension "Human - Nature". A dependent variable was components of ecological values formation in future teachers of biology, geography, chemistry and physics, separated, based on criteria and indicators. At using the method of interviewing, we understood that the dependent variable was influenced by both specially elaborated and used factors (author course "Axiopedagogy" and training "Ensuring the adoption and translation of professional values"), and independent ones, not completely taken into account by us at the experiment beginning, namely: family, informal youth associations, groups in social networks, selfeducation (conditioned by COVID-19) and so on).That is why for minimizing the influence of the independent variable on the dependent ones, we selected control groups, using the method of randomization, based on the pair design technology. As usually in such cases - the educational process in these groups took place by the traditional scheme - without using author innovations. In general, the methodology for diagnosing ecological values formation in future teachers of natural sciences was based on using traditional and innovative methods, allowed to estimate the separated studied phenomenon.

At the beginning of the experiment for preparing to introducing the first pedagogical condition - ecofocused nature understanding formation (by its upbringing in future teachers), we used the method "Ecological ideas", according to which second-year students - future teachers of natural sciences must demonstrate ecological ideas as to interconnections in the system "Human - Nature". At this stage it was important to develop students' understanding of ecological values at the human-focused 
level in harmony with eco-focused and nature-focused understanding of their nature protecting mission. Such ecological ideas must favor not only the complex formation of the value-ecological worldview, but also organization of the value-oriented activity. The last may be considered in several mutually connected aspects, based on a degree of contribution in public good:

- Nature protecting (organization of volunteer detachments on environment protection);

- Public-labor (cleaning of water bodies, forests, territory, adjacent to dwellings and so on);

- Culture-local lore (knowledge about rare varieties of plants and animals of own locality, preservation of their population; multiplication of eco-saving traditions);

- Scientific-searching (study of an ecological condition of own locality; search for ways for solving ecological problems).

Ecological ideas, illustrated the level of cognitive consciousness of second-year students, were determined in the unity of the aforementioned methodology and one of K. Nobl "Free successive associations". Associative notions that must stimulate students to ecological content description were "Human", "Nature", "Value". The respondents were offered to choose free (any) associations to these three keywords. We intentionally didn't limit the studied persons in time for more creative and cogitated choice.

For diagnosing the indicator of knowledge about "values" and "personal values", we used the psychodiagnostic method by S. Schwartz [5]. Before conducting the diagnostics by this method, at the ascertaining state of the experiments, the students were offered to write on a clean paper sheet what they exactly understand as the notion "values".

The technology of using this method is such: a questionnaire for respondents consists of two parts: just offered list of values and "Personal profile". According to indicated numbers of both parts of the questionnaire, there is calculated the average point of a value type that testifies to the level of its importance. Like in the first variant - we didn't limit the students in time (it took approximately from half an hour to hour). As far as the structure of the test for revealing personal-value advantages consists of two parts, in the first one ("Review of values"), we paid attention to studying normativevalue ideals, and also person's value at the level of convictions, content part of their components. So, the first part of the questionnaire consists of two lists of words, characterized 57 values, each of which has a distinct motivational aim and is to some extent important for representatives of different social cultures (in our case - future teachers of natural sciences of the three regions of Ukraine). The first list is presented by the reckoning of terminal values as words-nouns. The second one words-adjectives, denoted instrumental values. All future teachers of natural sciences were offered to estimate each value by the importance degree for him/her as a driving principle of their life by the scale from -1 to +7 . The higher the point within -1, 1, 2. 3. 4, 5, 6, 7, - the more important the value is for the respondent. At processing the results of the questionnaire "Review of values", they are summarized by two lists.
In the part "Personal profile", the aim was to study values of future teachers of natural sciences at the level of behavior, individual priorities, manifested in the social (first of all - educational) environment. 40 human characteristics, corresponding to one of 10 universal values, were given to respondents for consideration. They were offered to determine, to which extent the data, presented in the table, that characterized a certain human type, correspond to their own qualities. The questionnaire scale was transformed in points before interrogation and presented in the table, given to each one. The results were calculated according to special keys, presented in the method by S. Schwartz. At the primary processing of both types of the questionnaire, the average point was deduced for answers, chosen by a respondent, according to the key. The processing was conducted separately for each of ten types of personal values. The average point scale, relative to others, allowed us to make judgments about the importance degree of just this value type for each of future teachers of natural sciences. It is necessary to note, that the data, obtained in the first and second parts of the questionnaire for fourth-year students often didn't correspond. It may testify that personal values (especially, ecological) at the level of normative ideals are not always realized equally, because a non-typical, changeable educational environment is characteristic for students - future teachers of natural sciences: for ones of firsts years of study, it is completely "closed", determined by being within higher educational institutions, and for senior students - by correspondent practices (conduction of excursions, tourist expeditions, field practices and so on). The range ratio was established according to the average point by each type of values (range from 1 to 10 was assigned to each type). The first range the value type with the highest average point, the tenth range - value type with the least average index. The range from 1 to 3 meant the high importance for the respondent, whereas the range from 7 to 10 - the low one.

As to the list of ecological values, presented in our research as desired educational results and are connected with axiological plan competences formation in experts of specialty 014.15 General education (Natural sciences) of the first (bachelor) level of higher education, we used, from one point of view, the analytic apparatus of philosophical-theoretical analysis, from another one sociological research means.

We took into account different systems of ecological values, described in specialized literature, especially the following variants:

1) ecological values, common to mankind; socionature ecological values; personal-ecological values;

2) social ecological values; group (professional) eco-values; personal ecological values;

3) integrated socio-ecological values: of individual or social kind.

At the same time based on statements of known philosophical and eco-ethic conceptions, we separated ecological values with a principal importance just in the context of professional training of future teachers of natural sciences:

1) value of life in all its manifestations;

2) nature as value in itself;

3) value of harmony with nature; 
4) biocentrism as responsibility for the world of living beings;

5) healthy environment as a value;

6) high-quality life value (in ecological discourse);

7) value of ecological knowledge;

8) ecological image as a value.

For providing the maximal substantiation of the formed list of values, subject to diagnostics, we used social research methods. Especially, we formed a questionnaire for experts and student youth for revealing their position as to the list of topical ecological values, approved by them. We conducted the expert interrogation of teachers and students of five higher educational institutions (Rivne state humanitarian university (92 students), Cherkassy national university, named after Bogdan Khmelnitsky (59 students), Ternopil national pedagogical university, named after Volodimir Gnatyuk, Mukachevo state university (86 students), Glukhiv national pedagogical university, named after Olexandr Dovgenko (67 students) and National pedagogical university, named after M.P. Dragomanov (71 students) and national staff of NAPS of Ukraine, involved in the experimental study.

Attracted statements of known philosophical and eco-ethic conceptions, we separated ecological values that must be among educational results of professional training of future teachers of natural sciences and reflect axiological plan competences formation in experts of specialty 014.15 General education (Natural sciences) of the first (bachelor). There are:

1) value of life in all its manifestations;

2) nature as value in itself;

3) value of harmony with nature;

4) biocentrism as responsibility for the world of living beings;

5) healthy environment as a value;

6) high-quality life value (in ecological discourse);

7) value of ecological knowledge;

8) ecological image as a value.

For verifying the cognitive component by the indicator "conscious knowledge and understanding of ecological and axiological information, necessary for effective professional activity", test tasks, specially developed by ecological education specialists, were used [11]. According to testing results, levels of professional knowledge and possibility of their use were determined.

For verifying the same component by the indicator "conscious knowledge and understanding of the potential and perspectives of using ecological and axiological knowledge and also the ability to realize them at performing practical professional tasks and in other spheres of life activity", the questionnaire "Ecological ideas", form "Determination of possession level of ecological notions" by T. Evokimova were used; verbal associative method for diagnosing ecological directives of a human "EZOP"; questionnaire "Dominating directives, relative to nature" by S. Deryabo were used. It gave a possibility to determine formation levels of directives for future teachers of natural sciences at both ascertaining and forming stage of the experimental study. We also had a possibility to compare the formation level of the value- sense sphere (of dominating values) with the one of ecological directives (for example, pragmatic directives, expressed in desire for improving a material status, own welfare and correspondent orientation on values of the "low" kind, such as: material status, health, family safety and so on). The level of cognitive directions was separated at that.

For confirming the effectiveness of the second pedagogical condition - acknowledgment of ecological values, we diagnosed the value-motivation component of the author model.

For verifying the criterion of adoption of ecological values as motivating factors of pedagogical activity in the context of formation of the eco-focused type of nature understanding by the value-motivational component, the method "Diagnostics of motivational orientations in interpersonal communications was used" [7]. Its use was directed on determining the motivation level that would favor harmonization of subject-subject relations between participants of the educational process at assimilating both common and professional-ecological values. General (summary) parameters of absolute harmony of communicative orientations of interrogated persons allowed us further to understand better the adopton degree (or vice versa) of the system of ecological values of future teachers of natural sciences.

The indicator "understanding of the importance of ecological values for professional activity and other life activity spheres by creating preconditions for transition from the status of values of the terminal-positional character (value of knowledge and ideas of a certain type) to the status of values of the instrumental-behavior character (determinants of living, including professional behavior)" was verified by the method "Value orientations" by M. Rokeach, modified by V. Kalita. Its specificity was in fact that the values in the offered lists (terminal and instrumental) were determined just vice versa: the most important was assigned by the least evaluation point -1 , and the least important -10 . After that there had been determined the next value and set after the first chosen one, then this process was repeated with the rest of values, and least important of them were last in the offered list. After ranging, the values were considered in the aspect of their grouping around the content block - which center is the ecological-value base. Thus, there were separated "concrete" and "abstract" values. Instrumental values were grouped in ethical, communication, business, altruistic ones. We tried to establish an individual regularity, consisted in evaluation of professional-ecological values, such as: erudition (width of knowledge, high general culture); rationalism (ability to think logically and reasonably, to make cogitated, rational decisions); delicacy (care); ecological character (love to nature, ability to feel and to understand the surrounding world, care for plants and animals); toleration (of other's views and ideas, ability to forgive other's mistakes). In cases, when there was no logic regularity to trace, we talked about non-formation of the system of professionally important values or untruthful answers (light-minded attitude to tests performance) of the respondents [13].

The indicator "formation of the stable motivation of students as to adoption of ecological knowledge with the orientation on correspondent value-subject blocks, 
determining their professional-pedagogical directionality for realization of the ecologically reasonable behavior of the value-motivational component by the criterion adoption of ecological values as motivating factors of professional pedagogical activity in the context of formation of the eco-focused type of nature understanding" was determined by methods for diagnosing the intensity of subjective attitude to nature "Naturaphil" by V. Yasvin, S Deryaba and for determining formation peculiarities of ecological consciousness components (M. Khrolenko). M. Khrolenko's method (in the author modification as to students - future teachers of natural sciences) was used because of several important causes. The first one was that it helped to determine formation levels of readiness of future teachers of natural sciences to preserving the natural environment (high, middle, low) by all readiness components (content, motivational and sense). The second cause of just this choice was in fact that the chosen method gave a possibility to characterize the readiness, taking into account the type of ecological consciousness, determined among others by the method of O. Nabochuk (namely: technocratic type of consciousness, ecofocused, naturalistic, traditional, indefinite and so on). M. Khrolenko in the own study makes a conclusion that just future specialists with the dominating eco-focused type have the high level of the readiness for preserving the natural environment, so - are characterized by the high level of professional training [14].

The indicator in the part "adoption of ecological knowledge with the orientation on correspondent valuesubject blocks" was verified at the forming stage of the experiment, as a result of adoption of knowledge from the subject "Axiology" and skills, formed after conducting the author training. The determination of the professional-pedagogical directionality on realization of the ecologically reasonable behavior was favored by the vector modeling method by V. Yasvin, one of diagnostics of the intensity of subjective attitude to nature "Naturaphil" by V. Yasvin and S. Deryaba.

The third pedagogical condition - internal acceptance and ability to translation and realization of ecological values in educational-professional activity, needed verification at the stage of third and fourth component of the author model. The third - operationalactivity component by the indicator "practical realization of ecological values as reflection of internal acceptance and ability to translation and realization of ecological values in educational professional activity" was verified by the form "The method for determining the development level of ecological consciousness of senior pupils" by O. Nabochuk, adapted to the level of students -future teachers of natural sciences. At this research stage it was important for us to explain the problem of the level of personal importance at accepting ecologically oriented values and norms. At the stage of determining the possibility of translation of adopted ecological values and norms, the formation level of the valuesense readiness of future teachers of natural sciences for preserving the natural environment was established.

The indicator "ability to reflect own behavior, based on ecological values and eco-focused nature understanding" was verified using the method "Incomplete questions" by O. Gribanova and the method "Test for studying the development level of components of personal ecological consciousness" by O. Asafova. It gave us a possibility to analyze the practical experience of interaction between future teachers of natural sciences and external environment. Using the method by $\mathrm{O}$. Gribanova, we succeeded in analyzing the ability of future teachers of natural sciences to act according to natural laws.

\section{Research results and their discussion}

The research result is the formation of the system of scientific methods, allowing to determine the realization effectiveness of pedagogical conditions as to formation of ecological values by realization of the author course "Axiopedagogy" and training "Ensuring the adoption and translation of professional values". An important moment is that the chosen methods have been already practically verified in other research projects, and their results - acknowledged as proved and substantiated. At the same time we first used these methods as a methodological research system for analyzing first systematized and substantiated eco-values as desired results of the educational process. The pilot verification of the described methodological research system with the participation of students of the five higher educational institutions proved its validity and at the same time revealed certain problem moments (design of forms, processing methods, ways of generalization of obtained information). The last one needs additional work that will be performed further. In general, according to the results of the conducted study, it has been ascertained, that the results of the formation level of ecological values in students of the experimental groups essentially changed (detail data will be presented in the next work). In the experimental groups at the stage of forming experiment the number of students with the low formation level of ecological values essentially decreased (if in the ascertaining study it had been $38.25 \%$ - in EG1 and $41.53 \%$ - in $\mathrm{EG} 2$, at the end of the forming experiment remained only $17.35 \%$ - in EG1 and $15.03 \%$ - in EG2). Correspondingly, the number of students with the middle level of ecological values formation in EG1 was $48.21 \%$, in EG2 $53.19 \%$, that was by $19.71 \%$ and $17.53 \%$ higher than at the stage of ascertaining experiment respectively. At the end of the forming experiment the number of students with the high level of ecological values formation increased in average by $12 \%$. These results also testify to the enough readiness of the students to nature protecting volunteer activity. As for students of the control groups, the results didn't change by Student t-criterion at reliability levels 0.01 and 0.05 .

So, we think that we succeeded in achieving the interesting and scientifically promising result: elaborated the methodological research scheme as to evaluating the results of pedagogical conditions realization for ecological values formation in experts of specialty 014.15 General education (Natural sciences) of the first (bachelor) level of higher education

\section{Conclusions}

According to the aim of our study, we have determined and substantiated the context of the methodical approach to verification of the effectiveness of realiza- 
tion of certain pedagogical conditions of ecological values formation in future teachers of natural sciences. The following research tasks were performed within attaining the set aim:

1) The method for diagnosing formation levels of ecological values in future teachers of natural sciences has been constructed. Especially, there has been described and analyzed the methodological research scheme for introducing first systematized and substantiated eco-values in the educational process for achieving desired educational results.
2) According to the defined research tasks, the work presents peculiarities of using the method for diagnosing formation levels of ecological values in future teachers of natural sciences.

The pilot test of the described methodological research system has proved its validity in pedagogical practice.

The system of methods, separated in the work, will be further improved, because both the educational environment and ecological challenges of modernity are constantly changing.

\section{References}

1. Lytvyn, A., Matseyko, O. (2013). Methodological Principles of the Notion of "Pedagogical Conditions". Pedagogy and psychology of vocational education, 4, 43-63.

2. Blashkova, O. M. (2019). Formuvannia humanistychnykh tsinnostei studentiv pryrodnychykh spetsialnostei u navchalnovykhovnomu protsesi pedahohichnykh universytetiv. Kyiv, 227.

3. Hrytsai, N. B. (2016). Systema metodychnoi pidhotovky maibutnikh uchyteliv biolohii v pedahohichnykh universytetakh. Poltava, 526.

4. Vasylieva, M. P. (2004). Teoretychni osnovy deontolohichnoi pidhotovky pedahoha. Kharkiv, 38.

5. Demianiuk, V. V. (2019). Formuvannia u maibutnikh spetsialistiv z bukhhalterskoho obliku tsinnisnykh profesiinykh oriientatsii u fakhovii pidhotovtsi. Rivne, 20.

6. Molchaniuk, O. V. (2020). Teoretyko-metodolohichni zasady vykhovannia v maibutnikh uchyteliv biolohii tsinnisnoho stavlennia. Kyiv, 469.

7. Schwartz, S. H. (1992). Universals in the Content and Structure of Values: Theoretical Advances and Empirical Tests in 20 Countries. Advances in Experimental Social Psychology. Vol. 25, 1-65. doi: http://doi.org/10.1016/s0065-2601(08)60281-6

8. Rokeach, M. (1979). Understanding Human Values: individual and societal. New York: Free press, 322.

9. Ladanov, I. D., Urazaeva, V. A. (2002). Diagnostika motivatsionnykh orientatsii v mezhlichnostnykh kommunikatsiiakh / Sotsialno-psikhologicheskaia diagnostika razvitiia lichnosti i malykh grupp. Moscow: Izd-vo Instituta Psikhoterapii, 92-94.

10. Sull, D., Turconi, S., Sull, C. (2020). When It Comes to Culture, Does Your Company Walk the Talk? Management review. Available at: https://sloanreview.mit.edu/article/when-it-comes-to-culture-does-your-company-walk-the-talk/?fbclid= IwAR2hM0SJMFDwJS2DSgMSgTZMMKUIlx4r1wDVtMmIsISZ7cTyEJYn61ECs3g Last accessed: 18.09.2020

11. Karandashev, V. N. (2004). Metodika Shvartsa dlia izucheniia tsennostei lichnosti: kontseptsiia i metodicheskoe rukovodstvo. Saint Petersburg: Rech, 70.

12. Khrolenko, M. V. (2006). Formuvannia ekolohichnoi svidomosti maibutnikh vchyteliv pochatkovykh klasiv. Kyiv, 234.

13. Greben, N. F. (2007). Psikhologicheskie testy dlia professionalov. Minsk: Sovremennaia shkola, 496.

14. Petruk, V. H., Klymenko, M. O., Mudrak, O. V. (2011). Vstup do fakhu. Vinnytsia: UNIVERSUM-Vinnytsia, 203.

Received date 07.08.2020

Accepted date 11.09.2020

Published date 30.09.2020

Valentin Rogoza, Researcher, Department of Specialized Training, Institute of Pedagogy of the National Academy Pedagogical Sciences of Ukraine, Sichovykh Striltsiv str., 52-D, Kyiv, Ukraine, 04053

E-mail: rogoza_v@ukr.net 